\title{
Predicting Sense of Efficacy and Teachers' Job Satisfaction of Teachers from Their Perceptions of the Decision Participation
}

\author{
Tran Van Dat ${ }^{1}$ \\ ${ }^{1}$ Head of Academic Affairs Office, An Giang University, Vietnam \\ Correspondence: Tran Van Dat, Head of Academic Affairs Office, An Giang University, Vietnam
}

Received: February 11, 2016

Accepted: February 23, 2016

Online Published: February 24, 2016

doi:10.5430/ijhe.v5n2p59

URL: http://dx.doi.org/10.5430/ijhe.v5n2p59

\begin{abstract}
This study examines the hypothesis that teachers' perceptions of the decision participation may predict their teaching efficacy and job satisfaction. It examines data obtained from 197 secondary school teachers from 6 secondary schools to identify how teachers' perception of the decision participation varies, and the extent to which this predict teaching efficacy and job satisfaction. The results obtained from correlation and multiple regression analyses indicated that decision participation factors are positively related to teaching efficacy and job satisfaction. The findings show that decision participation should be supported to promote teaching efficacy and job satisfaction of teachers in schools.
\end{abstract}

Keywords: Teacher decision participation, Sense of efficacy, Job satisfaction

\section{Introduction}

Teachers' decision participation, teaching efficacy and their job satisfaction are three areas of research that have received much attention from researchers and policy makers in recent years (Ashton, Webb, \& Doda, 1983). Decision participation in an open school environment results in an increase in teachers' teaching efficacy and their job satisfaction (Taylor \& Bogotch, 1994). In Vietnamese secondary education the interrelationships among these variables are rarely addressed. Therefore, the aim of this study is to investigate the extent to which teacher perceptions about decision participation predicts their teaching efficacy and job satisfaction. Understanding the relationships among these factors is significantly important to efforts to improve schools effectively.

\section{Content}

\subsection{Predictor and Outcome Variables}

\subsubsection{Decision Participation}

Teachers' decision participation is the degree to which teachers in a school take part in decision making falls at some point on a continuum that ranges from full participation in parity with leaders to complete exclusion from involvement (Dachler \& Wilpert, 1978). It included three factors, managerial, instruction, and instructional materials (Taylor \& Bogotch, 1994). The results of some previous research studies indicated that teacher decision participation is positively related to their teaching efficacy and job satisfaction (Conway, 1984; Taylor \& Tashakkori, 2010). The present study defined decision making as teachers' reported influence in establishing school-level policies and procedures.

\subsubsection{Teaching Efficacy}

Teachers' sense of efficacy refers to teachers' beliefs about their capabilities to carry out a particular course of action successfully (Bandura, 1977). Teachers' sense of efficacy consisted of two factors, outcome expectancy (reflects a belief that effort expended will result in a wanted outcome), and efficacy expectancy (the extent to which an individual feels capable of influencing outcomes in the desired direction) (Taylor \& Tashakkori, 2010, p.220). Some previous research showed that teachers' sense of efficacy associated with school outcomes, such as student achievement gains (Ashton, Webb, \& Doda, 1983), successful school change efforts (Guskey, 1988). In this study, a single factor of teachers' sense of efficacy was identified that represented the extent to which a teacher feels capable of positively influencing student outcomes. 


\subsubsection{Job Satisfaction}

Job satisfaction is defined as a sense of fulfillment, gratification and satisfaction from working in an occupation (Locke, 1969). More specifically, it refers to the degree to which an individual feels that his or her job-related needs are being met (Evans, 1997). Job satisfaction is related with both extrinsic and intrinsic rewards. Extrinsic satisfaction comes from rewards dispensed by the organization, such as salary and benefits, promotion, status, a safe environment, and job security (Lawler \& Poter, 1967). Intrinsic sources of satisfaction reside within the individual and are related with performance (Lawler \& Poter, 1967). It is likely that opening opportunities for teachers to be involved in decision making may provide important sources of satisfaction. Identifying factors of decision making that are associated with sense of efficacy and teachers' job satisfaction can serve as a guide to those interested in school reform.

Until now no known study has examined the relations among decision participation, teaching efficacy and job satisfaction in the setting of Vietnamese secondary schools. The current study adds to the literature by reporting the results of an investigation to predict that decision making may be positively related to teachers' sense of efficacy and job satisfaction. The results of this study may provide Vietnamese secondary teachers as well as school leaders with potentially additional information to improve teachers' sense of efficacy and job satisfaction.

\subsection{Research Method}

A survey research design was utilized to examine correlations between decision participation factors and both the scales of sense of efficacy and job satisfaction. The sample used for this research consisted of 197 teachers (97 females and 101 males) from 6 Vietnamese government secondary schools.

This study used three instruments to examine the relationships among decision participation, sense of efficacy and job satisfaction. For each item of each instrument, respondents marked a 1, 2, 3, 4, or 5 for their response, the numbers corresponding to, SD (Strongly Disagree), D (Disagree), U (Undecided), A (Agree), SA (Strongly Agree), respectively.

Decision participation scale (Taylor \& Tashakkori, 2010) was used to examine teachers' perception of their decision participation. This scale consisted of 3 factors with 9 items. The first factor, called Managerial, contained 4 items (Influence over school discipline policy, influence over grouping students, Influence over curriculum, and Influence over in-service programs). The second factor, called Classroom procedures/teaching, consisted of 3 items (Control over classroom discipline, Control over teaching techniques, and Control over amount of homework). The third factor, called Instructional texts/materials, contained 2 items (Control over texts/materials and Control over content). Table 1 describes the means, standard deviations (SD), and alpha coefficient $(\alpha)$ of each factor.

Teachers' sense of efficacy scale (Taylor \& Tashakkori, 2010) comprised 6 items (Different methods can affect student achievement, I can get through to most difficult students, I am responsible for keeping students from dropping, I can change my approach if students are not doing well, I can do little to insure high achievement, and Teachers make a difference in students' lives). Table 1 describes the means, standard deviations (SD), and alpha coefficient $(\alpha)$ of this scale.

Job satisfaction scale (Taylor \& Tashakkori, 2010) consisted of 5 items (Teacher usually looks forward to each day, Teacher often feels satisfied with job, Teacher feels it's a waste of time to do best at teaching, and Teacher is happy just to get through day). Table 1 describes the means, standard deviations (SD), and alpha coefficient $(\alpha)$ of this scale.

Table 1. The means, standard deviations (SD), and alpha coefficient $(\alpha)$ of independent and dependent variables

\begin{tabular}{lllll}
\hline Variable & Mean & SD & Alpha $(\boldsymbol{\alpha})$ & No. Items \\
\hline Decision participation & & & & \\
Managerial (MA) & 3.72 & .69 & .73 & 4 \\
Classroom procedures/teaching (CP) & 3.99 & .77 & .81 & 3 \\
Instructional texts/materials (IT) & 3.87 & .71 & .79 & 2 \\
Sense of efficacy (SE) & 4.01 & .80 & .75 & 6 \\
Job satisfaction (JS) & 4.12 & .76 & .82 & 5
\end{tabular}

Note: $\mathrm{n}=178$ 


\subsection{Data Analysis}

The relationship among factors of decision participation and two scales of sense of efficacy and job satisfaction were investigated using the Pearson product-moment correlation coefficient. Multiple regression analyses were also conducted to determine if there were any sense of efficacy-decision participation and job satisfaction-decision participation associations. For all tests, the significance level was determined with $\mathrm{p}<.05$.

\subsection{Results and Discussion}

An analysis using Pearson's correlation coefficient indicates that correlations among the three variables of decision participation dimensions were statistically significant at the .01 level (2-tailed). The smallest relationship was $r$ (178) $=.17, \mathrm{p}=.004$ between CP scale and IT scale, followed by the MA scale and IT scale, $\mathrm{r}(178)=.18, \mathrm{p}=.006$. The largest relationship was $\mathrm{r}(178)=.24, \mathrm{p}=.002$ between MA scale and CP scale.

Table 2. Correlations between dependent variables (SE and JS) and predictor variables (MA, CP and IT)

\begin{tabular}{lllll}
\hline Variable & SE & \multicolumn{3}{l}{ JS } \\
\hline Decision participation & $\mathrm{r}$ & $\mathrm{p}$ & $\mathrm{r}$ & $\mathrm{p}$ \\
Managerial (MA) & $.26^{*}$ & .002 & $.19^{*}$ & .008 \\
Classroom procedures/teaching (CP) & $.31^{*}$ & .004 & $.23^{*}$ & .005 \\
Instructional texts/materials (IT) & $.28^{*}$ & .007 & $.12^{*}$ & .006 \\
\hline
\end{tabular}

Note: $\mathrm{n}=197$

* $\mathrm{p}<.01$

The descriptive statistics (Table 2) show that the bivariate correlations between scales of decision participation and both sense of efficacy and job satisfaction scales were statistically significant for all scales. The SE variable was positively correlated with the $\mathrm{CP}(\mathrm{r}=.31, \mathrm{p}=.004)$, the IT $(\mathrm{r}=.28, \mathrm{p}=.007)$, and the MA $(\mathrm{r}=.26, \mathrm{p}=.002)$. The JS variable was positively and significantly correlated with the $\mathrm{CP}(\mathrm{r}=.23, \mathrm{p}=.005)$, the $\mathrm{MA}(\mathrm{r}=.19, \mathrm{p}=.008)$, and the IT $(\mathrm{r}=.12, \mathrm{p}=.006)$.

Table 3 reports the results of the two multiple regression analyses on the predicted measures and dependent variables. The first model reports the results of regression analyses performed to predict teachers' sense of efficacy from decision participation variables. This model with all three predictors explained $37 \%$ of the variance in SE scale $\left(\mathrm{R}^{2}\right.$ $=.37), F=35.100, \mathrm{p}<.001$. The three variables of decision participation were positively and statistically significant related to SE scale, with the beta value of MA $(\beta=.14), \mathrm{CP}(\beta=.19)$, and IT $(\beta=.17)$. The results show that the CP factor was the strongest predictor of teachers' sense of efficacy. Consistent with the correlational findings, the strongest predictor of sense of efficacy was the CP, $\beta=.19$. This was followed by the IT, $\beta=.17$. The weakest predictor was the MA, $\beta=.14$

Table 3. Results from Multiple Regression Analyses

\begin{tabular}{|c|c|c|c|c|c|c|}
\hline \multirow[t]{5}{*}{ Variable } & \multicolumn{6}{|c|}{ Multiple Regression Weights } \\
\hline & \multicolumn{3}{|c|}{ Model 1 - SE scale } & \multicolumn{3}{|c|}{ Model 2 - JS scale } \\
\hline & $\mathrm{R}^{2}$ & $\mathrm{~F}$ & $\mathrm{p}$ & $\mathrm{R}^{2}$ & $\mathrm{~F}$ & $\mathrm{p}$ \\
\hline & .37 & 35.100 & .000 & .32 & 43.162 & .017 \\
\hline & $\beta$ & $\mathrm{t}$ & $\mathrm{p}$ & $\beta$ & $\mathrm{t}$ & $\mathrm{p}$ \\
\hline MA & $.14^{*}$ & 3.241 & .007 & $.12^{*}$ & 3.827 & .002 \\
\hline IP & $.19^{*}$ & 3.133 & .002 & $.42^{*}$ & 4.134 & .000 \\
\hline IT & $.17^{*}$ & 2.917 & .004 & $.16^{*}$ & 3.451 & .037 \\
\hline
\end{tabular}

a. Predictors: MA, IP, IT

b. Dependent variables: SE and JS

* $p<.05$ 
Similarly, the second model reports the results of regression analyses performed to predict teachers' job satisfaction from decision participation variables. This model with all three predictors produced $32 \%$ of the variance in JS scale $\left(\mathrm{R}^{2}=.32\right), F=43.162, \mathrm{p}<.05$. The three variables of decision participation were positively and statistically significant related to the JS scale, with the beta value of MA $(\beta=.12)$, the CP $(\beta=.42)$, and the IT $(\beta=.16)$. The results show that the CP factor was also the strongest predictor of teachers' job satisfaction. Consistent with the correlational findings, the strongest predictor of job satisfaction was the CP, $\beta=.42$. This was also followed by the IP, $\beta=.16$. The weakest predictor was also the MA, $\beta=.12$

The findings obtained from the two models indicated that teachers' sense of efficacy and their job satisfaction increase when they were given opportunity to involve important decisions at school. The results of this study are consistent with the findings of previous research (Conway, 1984; Taylor \& Tashakkori, 2010) which indicate a positively significant relationship between the factors of decision participation and factors of both teachers' sense of efficacy and their job satisfaction.

\section{Conclusion}

The three constructs examined in the present study including decision making, sense of efficacy and job satisfaction are discussed in this study in conjunction with school restructuring. The results of this study show that all factors of the decision participation significantly influence the sense of efficacy and job satisfaction of a group of Vietnamese secondary teachers. The correlation and multiple regression analyses obtained support the hypothesis that teachers' perceptions of the decision participation may predict their sense of efficacy and job satisfaction. It seems that, from the results obtained in this study, fostering teachers' involvement in decision making are the most necessary mandates of school leaders. Therefore, an open school environment should be created to promote the teachers' sense of professional efficacy and job satisfaction in Vietnamese secondary schools.

\section{References}

Ashton, P. T., Webb, R. B., \& Doda, N. (1983). A study of teachers' sense of efficacy (Final report, National Institute of Education Contract No. 400790075). Gainesville: University of Florida. (Eric Document Reproduction Service No. ED 231834).

Bandura, A. (1977). Self-efficacy: towards a unifying theory of behavioural change. Psychological Review, 84, 191-215. http://dx.doi.org/10.1037/0033-295X.84.2.191

Collie, R. J., Shapka, J. D., \& Perry, N. E. (2012). School climate and social-emotional learning: predicting teacher stress, job satisfaction, and teaching efficacy. Journal of Educational Psychology, 104(4), 1189-1204. http://dx.doi.org/10.1037/a0029356

Conway, J. A. (1984). The myth, mystery, and mastery of participative decision making in education. Educational Administration Quarterly, 20, 11-40. http://dx.doi.org/10.1177/0013161X84020003003

Dachler, H. P., \& Wilpert, B. (1978). Conceptual dimensions and boundaries of participation in organizations: a critical evaluation. Administrative Science Quarterly, 23, 1-36. http://dx.doi.org/10.2307/2392432

Evans, L. (1997). Understanding teacher morale and job satisfaction. Teaching and Teacher Education, 13, 831-845. http://dx.doi.org/10.1016/S0742-051X(97)00027-9

Guskey, T. R. (1988). Teacher efficacy, self-concept and attitudes toward the implementation of instructional innovation. Teaching and Teacher Education, 4, 63-70. http://dx.doi.org/10.1016/0742-051X(88)90025-X

Lawler, E. E., \& Poter, L. W. (1967). The effects of performance on job satisfaction. Industrial Relations, A Journal of Economy and Society, 7, 20-28. http://dx.doi.org/10.1111/j.1468-232X.1967.tb01060.x

Locke, E. (1969). What is job satisfaction? Organizational Behavior and Human Performance, 4, 309-336. http://dx.doi.org/10.1016/0030-5073(69)90013-0

Taylor, D. L., \& Bogotch, I. E. (1994). School-level effects of teachers' participation in decision making. Educational Evaluation and Policy Analysis, 16, 302-319. http://dx.doi.org/10.3102/01623737016003302

Taylor, D. T., \& Tashakkori, A. (2010). Decision participation and school climate as predictors of job satisfaction and teachers' sense of efficacy. Journal of Experimental Education, 63(3), 217-230. http://dx.doi.org/10.1080/00220973.1995.9943810

Tschannen-Moran, M., \& Woolf Hoy, A. (2007). Teacher efficacy: capturing an elusive construct. Teaching and Teacher Education, 17, 783-805. http://dx.doi.org/10.1016/S0742-051X(01)00036-1 